\title{
Study of prevalence of hemoglobinopathy in Sindhi community of Jamnagar, Gujarat: A pilot study
}

Viral M. Bhanvadia, Alpesh Chavda, Dhaval Mehta, Asha Satvara, Monika Parmar, Shamim S. Sheikh

Department of Pathology, M.P. Shah Government Medical College, Jamnagar, Gujarat, India

Address for the Correspondence:

Dr. Viral M. Bhanvadia, Department of Pathology, M.P.

Shah Government Medical College, Jamnagar, Gujarat, India. E-mail: drviral2001@gmail.com

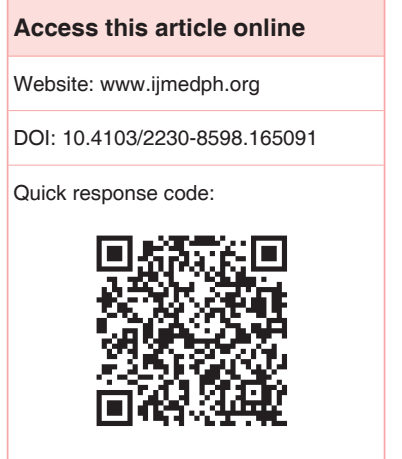

Introduction: Hemoglobinopathies are the most common hereditary disorders in India and pose a major health problem. A pilot study is carried out to find the prevalence of hemoglobinopathies in the Sindhi community of Jamnagar, district of Gujarat, India. Materials and Methods: The present cross-sectional study was undertaken among 109, apparently healthy Sindhi individual from community in Jamnagar, district of Gujarat, India from January to February 2015. All the samples were tested in automated hematology cell counter and cellulose acetate electrophoresis at alkaline $\mathrm{pH}$. Hemoglobin and various red blood cell indices were derived on all samples. HbA2 level of $\geq 3.8 \%$ was taken as confirmatory of Beta-thalassemia trait (BTT). Result: Of 109 samples, BTT and sickle cell trait (SCT) were more common in 12-21 years of male and female, respectively. The overall prevalence of hemoglobinopathy was $21 / 109(19.26 \%)$, comprised of $17(15.59 \%)$ cases of BTT and $4(3.66 \%)$ cases of SCT. Conclusion: Sindhi community has a high prevalence of hemoglobinopathy mainly BTT. Mass awareness and community screening of individual and proper counseling should be done to reduce the burden of disease.

Key words: Automated hematology cell counter, beta-thalassemia trait, cellulose acetate electrophoresis, sickle cell trait

\section{INTRODUCTION}

Hemoglobinopathy is characterized by a genetic defect that results in the abnormal structure of one of the globins of the hemoglobin ( $\mathrm{Hb}$ ) molecule. These inherited hemoglobinopathies are controlled by a single gene and are transmitted to progeny.

The carriers of $\mathrm{Hb}$ disorders in the world are estimated to be 269 million. ${ }^{[1]}$ About $3 \%$ of the world's population (150 million people) carry beta-thalassemia genes. In India, beta-thalassemia is the most common autosomal recessively inherited monogenic disorder with approximately 30 million carrying the defective gene, with carrier frequency ranging from $3 \%$ to $17 \%$.

As compared to other Indian states, hemoglobinopathy is more common in Gujarat. Modell and Petrou have estimated $12 \%$ incidence of major hemoglobinopathy traits in Gujarat. ${ }^{[2]}$ Some ethnic groups like Sindhis, Kutchis, Lohanas, Punjabis, few Muslim groups as well as few tribal population have a higher prevalence of beta-thalassemia carriers $(5-17 \%) \cdot{ }^{[3,4]}$

We have observed many cases of hemoglobinopathy among the Sindhi community of Jamnagar. Thus, the Pilot study is carried out in Sindhi community, who had migrated to India from Sindh province of Pakistan at the time of partition, to measure the approximate prevalence of the beta-thalassemia trait (BTT), sickle cell trait (SCT), and incidence of anemia among trait. This study provides a base to calculate the sample size in Sindhi community for the final study of hemoglobinopathies in future.

\section{MATERIALS AND METHODS}

A pilot study was carried out in Sindhi individual to estimate the approximate prevalence of BTT in Jamnagar, a district, located in the Western part of Gujarat, a state in India from January 2015 
to February 2015. Due to the availability of limited resources, feasibility, we have enrolled 109 subjects in this pilot study. We have tried to minimize selection bias. This study was done in the city area of Jamnagar, also planned similar study in the rural area. Selection criteria for the study are apparent healthy individual from Sindhi community residing in Jamnagar city. Exclusion criteria include community other than Sindhi, person residing outside Jamnagar city, diagnosed case of thalassemia major or sickle-cell disease. An informed consent was taken from parents of children and adolescents of $<18$ years and individuals before inducting in the study.

The information like name, age, sex, address, phone number, previous transfusion history, sibling history, consanguinity, any family history of blood disorders, etc., was filled in pretest pro forma.

Three milliliter of blood sample was collected in ethylene diamine tetra acetic acid tubes. Complete blood count was measured on the Sysmex KX-21 fully automated hematology cell analyzer to measure $\mathrm{Hb} \mathrm{g} / \mathrm{dl}$ and red blood indices like mean corpuscular volume (MCV), mean corpuscular hemoglobin $(\mathrm{MCH})$. Due to low sensitivity and specificity, screening naked eye single tube red cell osmotic fragility test was not done. Anemia is defined as $\mathrm{Hb}$ value in male and nonpregnant female below $13 \mathrm{~g} / \mathrm{dl}$ and $12 \mathrm{~g} / \mathrm{dl}$, respectively. ${ }^{[5]}$

The electrophoresis was done on cellulose acetate strip at alkaline pH 8.4 using Tris-buffer by Interlab Genios electrophoresis machine in all the cases. $\mathrm{HbA} 2, \mathrm{HbF}$, and $\mathrm{HbS}$ were estimated by graphs obtained from densitometry of $\mathrm{Hb}$ pattern. Mean cell hemoglobin $(\mathrm{MCH})$ is $<27 \mathrm{pg}, \mathrm{HbA} 2$ level of $\geq 3.8 \%$ indicates heterozygosity for beta-thalassemia (BTT). HbA2 value between 3.5\% and 3.7\% was considered as borderline $\mathrm{HbA} 2$, subjected to repeat testing from same and fresh sample. ${ }^{[6]}$

High-performance liquid chromatography (HPLC) on Bio-Rad $\mathrm{Hb}$ variant system was done on samples having borderline $\mathrm{HbA} 2$ value $(3.5-3.7 \%)$. For all cases showing band in $\mathrm{S}$ region in cellulose acetate electrophoresis were subjected for sickle solubility test. Sickle cell $\mathrm{Hb}$ is insoluble in the deoxygenated state in a high molarity phosphate buffer. The crystals that form refract light and cause the solution to be turbid. Positive solubility test merely indicates the presence of sickling Hb. Further HPLC was carried out to separate $\mathrm{HbS}$ from $\mathrm{HbD}$ and $\mathrm{HbG}$ and to confirm the presence of HbS. The data were collected and analyzed using Microsoft Excel software program. Abnormal results were communicated to the individual and counseling about lethal nature of the disease, nature of inheritance was done.

\section{RESULT}

We have divided all samples in premarital (12-21 years) and marital or childbearing (22-32 years) age groups, as both age groups need a different type of sensitization and counseling. There were no subjects $<12$ years or $>32$ years of age. Of 109 samples, 84 cases were between 12 and 21 years and 25 cases were between 22 and 32 years. 56 and 53 cases were from male and female, respectively. BTT is more common in 12-21 years of male. SCT is more common in 12-21 years of female.

Of 109 samples, 13 samples have HbA2 $\geq 3.8 \%$, and four samples have borderline HbA2 3.5-3.7\%. Repeat testing by electrophoresis and further testing by HPLC, these four samples have HbA2 $\geq 3.8 \%$, confirm the diagnosis of BTT. The overall prevalence of hemoglobinopathies was 21/109 (19.26\%), comprised of 17 $(15.59 \%)$ cases of BTT and 4 (3.66\%) cases of SCT [Table 1].

Eight and 6 cases of BTT with anemia were diagnosed in male and female, respectively. Two cases of SCT with anemia were diagnosed in female [Table 2].

All 4 cases showing band in S region in cellulose acetate electrophoresis were positive for sickle solubility test. Confirmation was done by HPLC shows band of HbS.

In BTT, mean MCH was $20.15 \mathrm{pg} / \mathrm{cell}$ and $21.15 \mathrm{pg} / \mathrm{cell}$ in the male and female, respectively. Mean MCV/red blood cell (Mentzer index) was 10.83 and 12.98 in the male and female, respectively, which also support the diagnosis of BTT [Table 3].

\section{DISCUSSION}

Hemoglobinopathy is a hematologic disorder due to alteration in the genetically determined molecular structure of $\mathrm{Hb}$. The India has an extreme diverse population of 1.21 billion. It comprises numerous castes, sub castes and tribal groups in the different geographic

\begin{tabular}{|c|c|c|c|c|c|}
\hline \multirow[t]{2}{*}{ Parameters } & \multirow[t]{2}{*}{ Total number } & \multicolumn{2}{|c|}{ BTT } & \multirow[t]{2}{*}{ SCT } & \multirow[t]{2}{*}{ Negative for hemoglobinopathy } \\
\hline & & HbA2 $\geq 3.8(\%)$ & HbA2 3.5-3.7 (\%) & & \\
\hline \multicolumn{6}{|l|}{ Age } \\
\hline $12-21$ & 84 & 9 & 3 & 3 & 69 \\
\hline $22-32$ & 25 & 4 & 1 & 1 & 19 \\
\hline Total (\%) & 109 & $13(11.95)$ & $4(3.66)$ & $4(3.66)$ & $88(80.73)$ \\
\hline \multicolumn{6}{|l|}{ Gender } \\
\hline Male & 56 & 8 & 3 & 1 & 44 \\
\hline Female & 53 & 5 & 1 & 3 & 44 \\
\hline Total $(\%)$ & 109 & $13(11.92)$ & $4(3.66)$ & $4(3.66)$ & $88(80.73)$ \\
\hline
\end{tabular}

BTT = Beta-thalassemia trait, $\mathrm{SCT}=$ Sickle cell trait 
region, each revealing different genetic traits and reservoir of hemoglobinopaties. Due to large scale migration of population and marriage across ethnic groups, the prevalence of hemoglobinopathy is quite variable.

It is estimated that about 100,000 children with transfusion-dependent thalassemia are born worldwide annually. About 8000-10,000 children with thalassemia major disease are born in India every year. ${ }^{[7]}$ It is seen with highest frequency in North-West and far East of India. Several studies in the literature have reported that Gujarat has a higher frequency of betathalassemia and sickle cell disease. ${ }^{[8-11]}$

In our pilot study, the overall prevalence of hemoglobinopathies in Sindhi community is $19.26 \%$. Prevalence of BTT is $15.59 \%$, which is an accordance with other study done by Sukumaran (12.2\%), Rakholia and Chaturvedi (17.2\%), Mulchandani et al. (16.81\%), Patel et al. $(10.2 \%)$, Pande et al. $(20.7 \%)^{[11-15]}$ [Table 4].

\begin{tabular}{lcccc}
\multicolumn{4}{l}{ Table 2: Gender and hemoglobin level distribution } \\
\hline Gender & Hemoglobin (g/dl) & Total number & BTT & SCT \\
\hline Male & $<10$ & 1 & 0 & 0 \\
& $10-12.9$ & 26 & 8 & 0 \\
& $\geq 13$ & 29 & 2 & 1 \\
Female & $<10$ & 4 & 0 & 1 \\
& $10-11.9$ & 19 & 6 & 1 \\
& $\geq 12$ & 30 & 1 & 1 \\
\hline
\end{tabular}

$\mathrm{BTT}=$ Beta-thalassemia trait, $\mathrm{SCT}=$ Sickle cell trait

\begin{tabular}{|c|c|c|c|c|c|}
\hline Parameters & $\begin{array}{l}\text { Hemoglobin } \\
\text { (g/dl) }\end{array}$ & $\begin{array}{c}\text { MCV } \\
\text { (fl) }\end{array}$ & $\begin{array}{c}\mathrm{MCH} \\
\text { (pg/cell) }\end{array}$ & $\begin{array}{c}\text { RBC } \\
\text { (million/ } \\
\text { cumm) }\end{array}$ & $\begin{array}{c}\text { MCV/RBC } \\
\text { (Mentzer } \\
\text { index) }\end{array}$ \\
\hline \multicolumn{6}{|l|}{ BTT } \\
\hline Male & 11.97 & 65.17 & 20.15 & 6.014 & 10.83 \\
\hline Female & 11.18 & 69.35 & 21.15 & 5.34 & 12.98 \\
\hline \multicolumn{6}{|l|}{ SCT } \\
\hline Male & 14.5 & 80.8 & 25.5 & 5.68 & \\
\hline Female & 9.96 & 80.9 & 27.3 & 3.6 & \\
\hline
\end{tabular}

BTT = Beta-thalassemia trait, $\mathrm{SCT}=$ Sickle cell trait, $\mathrm{MCV}=$ Mean corpuscular volume, $\mathrm{MCH}=$ Mean corpuscular hemoglobin, $\mathrm{RBC}=$ Red blood cell

\begin{tabular}{lccl}
\hline $\begin{array}{l}\text { Table 4: Result of prevalence studies in sindhi } \\
\text { community }\end{array}$ \\
\hline Study conducted by & $\begin{array}{c}\text { Number } \\
\text { tested }\end{array}$ & $\begin{array}{l}\text { Prevalence } \\
\text { of BTT (\%) }\end{array}$ & State, region \\
\hline Sukumaran et al. & 82 & 12.2 & $\begin{array}{l}\text { Ulhasnagar, } \\
\text { Maharashtra }\end{array}$ \\
Rakholia and Chaturvedi & 550 & 17.2 & $\begin{array}{l}\text { Wardha, } \\
\text { Maharashtra }\end{array}$ \\
Mulchandani et al. & 446 & 16.81 & $\begin{array}{l}\text { Nagpur, } \\
\text { Maharashtra } \\
\text { South Gujarat } \\
\text { Jabalpur, } \\
\text { Pande et al. }\end{array}$ \\
\hline
\end{tabular}

BTT = Beta-thalassemia trait
Prevalence of SCT is $3.66 \%$. All four cases were confirmed by HPLC Bio-Rad system as SCT. In cellulose acetate electrophoresis, $\mathrm{HbS}$ migrates along with $\mathrm{HbD}$ and $\mathrm{HbG}$. Hence, it is necessary to confirm the diagnosis by sickle solubility test and HPLC.

In the present study, out of 21 cases of hemoglobinopathies, 16 cases were anemic comprised of 8 cases of male and female, respectively. In our study, anemia was not treated before performing HbA2 estimation.

Severe iron deficiency anemia $(\mathrm{Hb}<8 \mathrm{~g} / \mathrm{dl})$ can reduce the $\mathrm{HbA} 2$ level by up to $0.5 \%$. Anemia is to be treated, and the $\mathrm{Hb}$ analysis repeated when the patient is iron replete. ${ }^{[16]}$

Iron deficiency anemia is commonly misdiagnosed in BTT and SCT subjects. Inadvertent iron treatment may harm the patient and physician should advise estimation of $\mathrm{HbA} 2$ to diagnose BTT in high-risk community.

An increased HbA2 level ( $\geq 3.8 \%$ ) along with $\mathrm{MCH}<27 \mathrm{Pg}$ is the hallmark of heterozygosity of BT'T. HbA2 level $<3.7 \%$ probably due to silent mutation, co-inheritance of $\delta$ and $\beta$-thalassemia, some mild $\beta$-gene mutations, $\gamma \delta \beta$-thalassemia, $\mathrm{HbH}$ disease, severe iron deficiency, erythroleukemia, and sideroblastic anemia should be repeated on HPLC and may be analyzed by molecular methods. ${ }^{[17]}$

Artifact in the presence of $\mathrm{HbS}$, hypothyroidism, megaloblastic anemia, patient on anti-retroviral therapy and hypertrophic osteoarthropathy may cause elevated HbA2 value. ${ }^{[17]}$ These preanalytic factor is important while interpreting elevated $\mathrm{HbA} 2 \%$.

With best of our Knowledge as this is a first study conducted in this community in Jamnagar city. One of the limitations of this study is small sample size, so that could affect the prevalence of hemoglobinopathy. There is a need for screening of whole population by calculating sample size from the pilot study in highrisk Sindhi community in near future.

Abnormal results are explained, and genetic counseling was done to individual affected. Those unmarried individual, explained regarding inheritance of disease, and the need to prevent marriage to traits. Those married individual explained regarding prenatal diagnosis, nature of inheritance, and selective termination of pregnancy of the affected fetus and preconceptional counseling for future.

\section{CONCLUSION}

Sindhi community has higher prevalence of hemoglobinopathy, mainly BTT. The most effective approach to minimize the problem of hemoglobinopathies in India is to sensitization and screening of individual, genetic counseling, proper health education regarding the nature of inheritance and prenatal diagnosis in a high-risk community. More efforts are needed to increase awareness in high-risk communities like Sindhi regarding thalassemia before the dream to control hemoglobinopathy in India. 


\section{ACKNOWLEDGMENT}

We are thankful to Dr. P.M. Santwani, Professor and Head, Department of Pathology and Dr. Nandini J. Desai, Professor of Pathology for help to conduct this study.

\section{REFERENCES}

1. Angastiniotis M, Modell B. Global epidemiology of hemoglobin disorders. Ann N Y Acad Sci 1998;850:251-69.

2. Modell B, Petrou M. The problem of the hemoglobinopathies in India. Indian J Hematol 1983;1:5-16.

3. Madan N, Sharma S, Sood SK, Colah R, Bhatia LH. Frequency of B-thalassemia trait and other hemoglobinopathies in northern and western India. Indian J Hum Genet 2010;16:16-25.

4. Mohanty D, Colah RB, Gorakshakar AC, Patel RZ, Master DC, Mahanta J, et al. Prevalence of $B$-thalassemia and other haemoglobinopathies in six cities in India: A multicentre study. J Community Genet 2013;4:33-42.

5. World Health Organization. Hemoglobin concentrations for the diagnosis of anemia and assessment of severity. Available from: http://www.who.int/ vmnis/indicators/haemoglobin.pdf. [Last accessed on 2015 Apr 13].

6. Wild B, Bain BJ. Investigation of abnormal haemoglobins and thalassemia. In: Lewis SM, Bain BJ, Bates I, editors. Dacie \& Lewis Practical Haematology. Philadelphia: Churchill Livingstone; 2011. p. 303.

7. Colah RB. Strategies for prevention of thalassemia and hemoglobinopathies. J Assoc Physicians India 1994;42:810-4.

8. Bhatia HM, Shanbagh SR, Baxi AJ, Bapat JP, Sharma RS. Genetic studies among the endogamous groups of Lohanas of North and West India. Hum Hered 1976;26:298-305.

9. Mukherjee MB, Gangakhedkar RR, Sathe MS. Abnormal hemoglobin, G6PD deficiency and their pattern of interaction in the tribal population of Valsad district (Gujarat). Indian J Hematol Blood Transfus 1993;11:227-31.

10. Vyas GN, Bhatia HM, Sukumaran PK, Balkrishanan V, Sanghvi LD. Study of blood groups, abnormal hemoglobins and other genetical characters in some tribes of Gujarat. Am J Phys Anthropol 1962;20:255-65.

11. Sukumaran PK. Abnormal hemoglobins in India. In: Sen NN, Basu AK, editors. Trends in Hematology. Kolkata, India: Saraswati Press; 1975. p. 225-36.

12. Rakholia R, Chaturvedi P. Prevalence of $B$ thalassemia carrier state in Sindhi community of Wardha and evaluation of risk factors for $B$ thalassemia trait. Niger J Clin Pract 2013;16:375-80.

13. Mulchandani DV, Fulare MB, Zodpey SP, Vasudeo ND. Prevalence and some epidemiological factors of beta thalassaemia trait in Sindhi community of Nagpur City, India. Indian J Public Health 2008;52:11-5.

14. Patel AG, Shah AP, Sorathiya SM, Gupte SC. Hemoglobinopathies in South Gujarat population and incidence of anemia in them. Indian J Hum Genet 2012;18:294-8.

15. Pande PL, Singh MP, Choudhary NK. Occurrence of thalassemia among the Sindhi Community of Jabalpur, Madhya Pradesh (Central India). J Hum Ecol 2005;17:157-8.

16. Ryan K, Bain BJ, Worthington D, James J, Plews D, Mason A, et al. Significant haemoglobinopathies: Guidelines for screening and diagnosis. Br J Haematol 2010;149:35-49.

17. Stephens AD, Angastiniotis M, Baysal E, Chan V, Fucharoen S, Giordano PC, et al. ICSH recommendations for the measurement of haemoglobin A2. Int J Lab Hematol 2012;34:1-13.

How to cite this article: Bhanvadia VM, Chavda A, Mehta D, Satvara A, Parmar M, Sheikh SS. Study of prevalence of hemoglobinopathy in Sindhi community of Jamnagar, Gujarat: A pilot study. Int J Med Public Health 2015;5:349-52.

Source of Support: Nil, Conflicts of Interest: None declared. 